\title{
ANNOUNCEMENTS
}

The 157th meeting of the

PATHOLOGICAL SOCIETY OF GREAT BRITAIN AND IRELAND will be held at the UNIVERSITY OF NEWCASTLE-UPON-TYNE on July 6th, 7th and 8th, 1988

Further information may be obtained from the Meetings Secretary:

Professor E. Mary Cooke, Central Public Health Laboratory, Division of Hospital Infection, 61 Colindale Avenue, London NW9 5HT. Tel: 01-200 4400 Ext 4249.

\section{THE WORLD ASSOCIATION OF VETERINARY MICROBIOLOGISTS, IMMUNOLOGISTS AND SPECIALISTS OF INFECTIOUS DISEASES}

\author{
First World Congress \\ LYON, France \\ July 25 th-29th, 1988
}

The programme includes new developments in animal bacteriology, virology, immunology and infectious diseases of domestic animals.

Also new diagnostic methods, prevention and therapy of these diseases are included. A special session will be reserved for the zoonoses.

The Congress will be of interest not only to specialists working in diagnostic, protection and quality control laboratories but also to veterinarians dealing with infectious diseases of different animal species as well as colleagues specialised in Public Health.

Further information from:

\author{
Professor Y. Richard, \\ École Nationale Vétérinaire de Eyon, \\ route de Sain Bel, Marcy-l'Etoile, \\ 69260 Charbonnières-les-Bains, Lyon, France.

\section{Vth INTERNATIONAL SYMPOSIUM ON BIOLUMINESCENCE AND CHEMILUMINESCENCE Florence, Bologna-Italy, September 25-29, 1988}

The Symposium in Florence will cover the fundamental aspects and the most recent applications of Bioluminescence and Chemiluminescence in clinical sciences, biotechnology, genetics, microbiology, phagocytosis, immunoassay, environmental monitoring.

The Symposium will consist of Invited Lectures, Short Communications, Poster Sessions and Workshops.

“Alma Mater Studiorum Saecularia Nona": the meeting will include a special Symposium on 27th September 1988 in Bologna as part of the Celebration to mark the Foundation of the University of Bologna in the XIth Century.

Further information is available from:

Prof. Mario Pazzagli, Endocrinology Unit, University of Florence, Viale Morgagni, 85, 50134 Florence, Italy

Deadline for Abstracts: 15th March 1988 


\section{Notice}

Arthur Andersen and Company in conjunction with Hassall and Associates Pty Ltd have been commissioned by the Australian Meat and Livestock Research and Development Corporation to undertake a study which examines the basis for, purpose and conduct of, meat inspection in Australia.

We have been specifically directed to undertake a thorough re-examination of current procedures to determine those which are necessary to maintain the public health requirements of the meat inspection services.

We are eager to identify and examine recent and current research which may be applicable to meat inspection. If any readers are currently conducting relevant research or can identify areas which offer technological advances from research, we would be most grateful to hear from them.

Address:

PO Box 405, Spring Hill,

Queensland, Australia 4004

\section{Erratum}

Stephenson J R, Millership S E, TABAQCHALI S 1987 Typing of Aeromonas species by polyacrylamide-gel electrophoresis of radiolabelled cell proteins. Journal of Medical Microbiology 24: 115-118.

Within the Results section on p. 116, under the heading of Reproducibility, the corrected paragraph should read as follows.

The mean difference between coefficients of 31 repeatedly tested pairs of isolates was $9.4 \% \ldots$ With these criteria, none of the 31 pairs differed in category on repeated testing. 